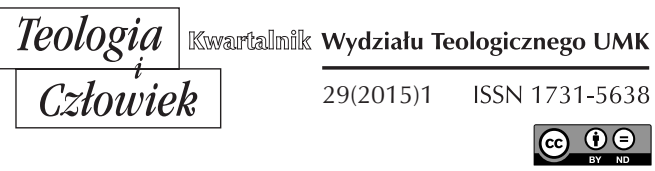

MIROSŁAW RUCKI*, MICHAEL ABDALLA, ASHRAF BENYAMIN

POZNAŃ

\title{
JAJKA WIELKANOCNE W POCZĄTKACH CHRZEŚCIJAŃSTWA
}

DOI: http://dx.doi.org/10.12775/TiCz.2015.013

\section{WPROWADZENIE}

Nikt z nas nie wyobraża sobie Wielkanocy bez kolorowych pisanek. Są one nieodzownym elementem naszych święconek, a w dzisiejszym skomercjalizowanym świecie wraz ze świeżo wyklutymi kurczaczkami pisanki obowiązkowo zdobią każdy supermarket $\mathrm{w}$ okresie świąt. Ewidentnie zwyczaj ten nie ma uzasadnienia biblijnego. Jajko bowiem pojawia się $\mathrm{w}$ Piśmie św. zaledwie 7 razy $^{1}$, z czego w Nowym Testamencie tylko raz w Łk 11,12 w kontekście niezwiązanym z Wielkanocą. Niemniej jednak Kościół akceptuje i wykorzystuje znaki i symbole,

* Dr hab. inż. Mirosław Rucki, były pracownik Politechniki Poznańskiej, gdzie w 2012 r. uzyskał tytuł doktora habilitowanego inżyniera. Autor ponad 120 artykułów naukowych z dziedziny budowy i eksploatacji maszyn. Obecnie pełni funkcję zastępcy redaktora naczelnego czasopisma „Miłujcie się!”.

1 J. Flis, Konkordancja Starego i Nowego Testamentu do Biblii Tysiąclecia, Warszawa 1996, s. 393. 
których „znaczenie ma swoje korzenie w dziele stworzenia i w kulturze ludzkiej"2.

Najstarsze pisanki znalezione $\mathrm{w}$ czasie wykopalisk na ziemiach polskich pochodzą z X wieku ${ }^{3}$, ale badania wskazują na istnienie zdobionych jajek u Słowian już w III w. ${ }^{4}$, czyli w czasach przedchrześcijańskich. O zwyczaju barwienia jaj przed pojawieniem się chrześcijaństwa wspomina Owidiusz ${ }^{5}$, co wskazywałoby na pogańskie pochodzenie tego symbolu ${ }^{6}$. Jednak związek jajka $\mathrm{z}$ obchodami Wielkiejnocy może mieć charakter wybitnie żydowski, gdyż Kościół pierwszego wieku miał bardzo głębokie związki z judaizmem, zarówno emocjonalne (większość wyznawców Chrystusa w pierwszej połowie I w. wywodziła się z judaizmu) ${ }^{7}$, jak i liturgiczne ${ }^{8}$. Dotyczy to nie tylko przebiegu nabożeństwa, ale też wystroju kościołów; jak zauważa D. Brzeziński, „katedra, podest, pulpit, czy też inne miejsce podwyższone jak bima [...] znane były w żydowskiej przestrzeni synagogalnej"'.

${ }^{2}$ Katechizm Kościoła Katolickiego, 1145.

${ }^{3}$ J. Lipka, O jajku prawie wszystko, czyli o wielkim dziele sztuki na małej skorupce, Opole 2005, s. 5.

${ }^{4}$ С. Килимник, Український рік у народних звичаях в історичному освітленні, кн. 2 т. 3, Київ 1994, s. 189.

5 Z. Gloger, Rok polski w życiu, tradycji i pieśni, Warszawa 1900, s. 171.

${ }^{6} \mathrm{Na}$ tej podstawie niekiedy kwestionuje się chrześcijańską symbolikę jajek, zob. np. artykuł w „Newsweeku” zatytułowany Jajko symbolem Wielkanocy? Nie do końca... (http://polska.newsweek.pl/jajko-symbolem-wielkanocy--nie-do-konca---,75697,1,1.html dostępna 20.10.2014 r.).

7 Masowe nawrócenia pogan rozpoczęły się dopiero w latach 40. I wieku, a w latach 50., kiedy św. Paweł został zaaresztowany w Jerozolimie, mieszkały tam tysiące Żydów wyznających wiarę w Chrystusa (Dz 21,20). Więcej o roli Żydów w Kościele I wieku zob. M. Rucki, Modlitwa Pańska w kontekście mentalności żydowskich adresatów Ewangelii Mateusza, Wrocław 2014, s. 137-183.

${ }^{8}$ Nie podlega dyskusji, że najważniejsze elementy liturgii chrześcijańskiej są wzięte z judaizmu; niezaprzeczalnie błogosławieństwo chleba i wina, jak i obmycie rąk, nie były nowymi obrzędami wprowadzonymi przez Jezusa w czasie Ostatniej Wieczerzy. W każdy szabat oraz w czasie sederu (kolacji Paschalnej) rodzina żydowska od wieków wykonywała te czynności.

9 D. Brzeziński, Aula liturgiczna: ku ponownemu odkrywaniu teologiczno-liturgicznego sensu, „Teologia i człowiek” Vol. 23 (2013) 3, s. 137-148. 
Wydaje się, że jajko jako element świętowania Wielkanocy pojawiło się już w pierwszych wiekach, gdyż spotkać je można i w Kościele rzymskim, i w Kościołach wywodzących się z Antiochii, i w Kościele koptyjskim. Mało znane w Polsce są tradycje Kościołów orientalnych oraz judaizmu, z którego przecież chrześcijaństwo się wywodzi, dlatego tym właśnie tradycjom poświęcony jest niniejszy artykuł. Przeprowadzona analiza wskazuje na starożytne powiązania symboliki jajek z okresem wielkanocnym oraz na możliwość tego, że impulsem dla tego powiązania było wprowadzenie ich do liturgii paschalnej w judaizmie.

\section{JAJKO W JUDAIZMIE}

Paradoksalnie, dla Żydów jajko nie jest symbolem życia, tylko symbolem żałoby. Talmud wprawdzie nie zakazuje spożywania jaj w święta, jednak w traktacie Bechorot 8a sugeruje, że w święto jajko można spożywać tylko wtedy, jeśli w przeddzień święta nie znaleziono jajek w gnieździe, a wczesnym rankiem jajo już tam było. Jednak rabini talmudyczni zajmowali się raczej zagadnieniami prawnymi niż symboliką, interesowało ich np. czy nie jest pracą zabranie jajka $\mathrm{z}$ gniazda w szabat (Szabat 43a) albo czy wolno w szabat posolić jajko (Szabat 108b) lub wstawić je na gotowanie w piątek przed zachodem słońca, by się ugotowały już po nadejściu szabatu (Szabat 18b), oraz czy można jajko jeść z mlekiem (Beica 6b), i co robić z jajkiem nieczystych ptaków lub ze znajdującą się w środku kroplą krwi (Chulin 64b). Generalnie uczniowie Szammaja twierdzili, że jajko złożone w święto może być zjedzone tego samego dnia, uczniowie Hillela utrzymywali zaś, że dopiero po zakończeniu święta (Beica 2a), jednak nic nie wskazuje na to, by te spory związane były z jakąkolwiek symboliką. Z kolei w traktacie Awoda Zara 46a rozważany jest problem jajek, które były przedmiotem kultu pogańskiego.

Jajko jako pokarm żałoby spożywa się zwłaszcza na pamiątkę zburzenia Świątyni Jerozolimskiej - tego samego dnia 9 Aw według kalendarza żydowskiego zarówno w roku 586 przed Chr. przez Nebukadnezara, jak i w 70 po Chr. przez Rzymian, a po stłumieniu powstania żydowskiego 
w roku 135 Turnus Rufus w tym samym dniu rozkazał zaorać Wzgórze Świątynne, by Świątynia nie została już odbudowana ${ }^{10}$.

Seuda mafseket ${ }^{11}$, ostatni posiłek przed rozpoczęciem postu Tisza b-Aw ${ }^{12}$, jest opisany w Talmudzie, np. Taanit 30a-b. Mówi się tutaj o tym, że nie wolno wówczas spożywać mięsa i pić wina, oraz podaje się przykład praktyki prywatnej rabbiego Jehudy Bar Ilaja spożywania wyłącznie suchego chleba $\mathrm{z}$ solą, popijanego wodą, w stanie żałoby, takim jak gdyby leżał przed nim zmarły bliski krewny. Wprawdzie Talmud nie wspomina $\mathrm{w}$ tym miejscu o jajku ${ }^{13}$, jednak zwyczajowo jest ono często maczane w popiele i spożywane $\mathrm{w}$ czasie seuda mafseket ${ }^{14}$ jako danie żałobne ${ }^{15}$. Rabbi Lawrence Hajioff wyjaśnia, że okrągły kształt jajka przypomina osobom w żałobie, że śmierć jest elementem cyklu życia oraz że po złym okresie na pewno nadejdą dobre czasy ${ }^{16}$. Łatwo zauważyć, że jajko w judaizmie, choć występuje jako część składowa posiłku żałobnego, zawiera w swojej symbolice element nadziei.

Jaki jednak jest związek jajka - symbolu żałoby - z obchodami Wielkanocy? Paschalna Wieczerza, którą Pan Jezus odprawił według ściśle określonego żydowskiego porządku, nazywana jest po hebrajsku Seder ('porządek'). W tym porządku był przaśny ${ }^{17}$ chleb, gorzkie zioła,

10 Zob. np. objaśnienia w modlitewniku Sidur Sza’arej Tfila (Aszkenaz), Jeruzalem-Moskwa 1993, s. 671.

11 Dosłownie „posiłek oddzielający”.

12 9. dzień żydowskiego miesiąca Aw jest obchodzony przez żydów jako dzień zburzenia Jerozolimy, czyli dzień żałoby narodowej.

13 O spożyciu jajka jako przykazaniu halachicznym mówi natomiast traktat Eruwin 41a, ale też nie wspomina o symbolice żałoby.

${ }_{14}$ Zob. np. Sh. Simmons, Tisha B'Av - The Ninth of Av, http://www.aish.com/ h/9av/oal/48944076.html [dostęp 20.10.2014 r.].

15 Zob. np. wskazówki na stronie rabbiego J. Scheinermana http://scheinerman. net/judaism/Holidays/tishabav.html [dostęp 20.10.2014 r.].

${ }^{16}$ The Meal Before Tisha B'Av - Seudah Hamafseket, artykuł w sekcji Ask a rabbi na stronie Joy of Kosher, http://www.joyofkosher.com/2013/07/the-meal-before-tisha-bavseudah-hamafseket/ [dostęp 20.10.2014 r.].

17 Ewangeliści nazywają ten dzień Świętem Przaśników (np. Mt 26,17). 
mięso baranka paschalnego ${ }^{18}$, wino, obmycie rąk, błogosławieństwa ${ }^{19}$, opowiadanie o wyjściu z Egiptu ${ }^{20}$, uroczysta kolacja i śpiewanie Psalmów ${ }^{21}$. Z pewnością jednak jajko nie było spożywane przez Jezusa i Apostołów, ponieważ zostało ono włączone do Sederu później, jako ,jedzenie żałobne na pamiątkę po zburzeniu Bet Hamikdasz (Świątyni Jerozolimskiej)"22.

Od roku 70 n.e., kiedy Rzymianie zburzyli Świątynię w Jerozolimie, składanie ofiar (w tym również ofiary baranka paschalnego) stało się niemożliwe. Naród żydowski rozpoczął swoją dwutysiącletnią tułaczkę, pozbawiony swojego kraju, Świątyni i kapłanów ${ }^{23}$ - bez których judaizm nie jest w pełni judaizmem. Dlatego rabini włączyli do każdego radosnego obrzędu jakiś element żałoby, mający przypominać Żydom, że jedynie powrót do Ojczyzny i odbudowanie Świątyni da im możliwość przeżywania pełni szczęścia. Najbardziej znanym przykładem jest obowiązkowe tłuczenie pucharu na pamiątkę zburzonej Świątyni po zakończeniu obrzędu kiduszin w czasie zaślubin ${ }^{24}$. Do takich żałobnych znaków należy również jajko jako obowiązkowy element Sederu w judaizmie po zburzeniu Świątyni.

Skąd jednak się wzięło jajko w chrześcijańskim świętowani Zmartwychwstania Chrystusa, skoro nie spożywał go Jezus Chrystus z Apostołami w czasie Ostatniej Wieczerzy?

Wydaje się prawdopodobne, że wyznawcy Chrystusa żydowskiej narodowości włączyli je do liturgii paschalnej jako znak żałoby i współcierpienia z resztą Izraela. Pismo Święte wielokrotnie podkreśla, że Apostołowie i inni członkowie jerozolimskiego Kościoła regularnie chodzili do Świątyni, gdzie się modlili i nauczali (np. Dz 3,1; 5,21), a nawet skła-

${ }^{18}$ Mt 26,17 wspomina o przygotowaniu Paschy, czyli upieczonego baranka, który był nazywany Paschą, np. „Odłączcie i weźcie baranka dla waszych rodzin i zabijcie jako paschę" (Wj 12,21).

19 Mt 26,26.

${ }^{20}$ Ten element Wieczerzy Paschalnej nie jest wprawdzie wzmiankowany w Ewangeliach, jednak starożytne fragmenty Hagady na Pesach stwierdzają: „obowiązkiem naszym jest opowiadać o wyjściu z Egiptu” (zob. np. Hagada, Wiedeń 1927, s. 11) i przytaczają przykłady takiego opowiadania z I w.

21 Mt 26,30.

${ }^{22}$ Hagada na Pesach, red. S. Pecaric, Kraków 2002, s. 52.

23 Taki stan rzeczy zapowiada proroctwo Ozeasza 3,4.

${ }^{24}$ Zob. np. komentarz w modlitewniku Sidur Sza’arej, s. 201. 
dali ofiary. Jeszcze w latach 50. I wieku Apostołowie mówili o tysiącach wiernych pochodzenia żydowskiego, którzy "trzymają się gorliwie Prawa” (Dz 21,21). Kiedy czytamy w Nowym Testamencie o tym, że św. Paweł wraz z czterema mężczyznami złożył śluby nazyreatu, pokrywając za nich koszty (Dz 21,23-24), musimy mieć na uwadze, że nazyreat był związany przede wszystkim ze złożeniem przepisanych ofiar (korban) w Świątyni, składających się z baranka jednorocznego jako ofiary całopalnej (olah), jednorocznej owieczki bez skazy na ofiarę przebłagalną (chattat) i barana bez skazy jako ofiary biesiadnej (szelamim). Poza tym składano w ofierze kosz chlebów przaśnych z najczystszej mąki zaprawionej oliwą i przaśne podpłomyki posmarowane oliwą, łącznie z przynależną do nich ofiarą pokarmową (mincha) i płynną (nesek). Koszty więc nie były małe i św. Paweł zgodził się zapłacić za wszystkie te ofiary składane w związku z własnymi ślubami nazyreatu, jak i ślubami czterech innych Żydów, wierzących w Jezusa Chrystusa. Możemy więc wnioskować, że pomimo wrogości głównych nurtów judaizmu wobec nowej „sekty nazarejczyków” ${ }^{25}$ sami wierni żydowskiego pochodzenia uważali siebie za żydów.

Istnieje bardzo duże prawdopodobieństwo, że sytuacja się zmieniła na początku lat 60. I wieku, i to $\mathrm{z}$ powodu zamordowania św. Jakuba zwanego Sprawiedliwym na polecenie arcykapłana Ananusa ${ }^{26}$. Zabójstwo Jakuba Sprawiedliwego pokazało, że to judaizm świątynny, który jest w stanie zaakceptować każdą sektę żydowską, nawet najbardziej wrogą, nie toleruje w swoim narodzie wyznawców Jezusa. Reakcją na to było napisanie przez rabinów rzymskich, uczniów św. Pawła, odezwy do wyznawców Chrystusa w Jerozolimie znanej nam jako biblijny List do Hebrajczyków ${ }^{27}$, w którym całe trzy rozdziały 8-10 zostały poświęcone zagadnieniu składania ofiar w Świątyni. Konkluzje są jednoznaczne: „uświęceni jesteśmy

${ }^{25}$ Oskarżyciele św. Pawła mówią o nim, że „jest przywódcą sekty nazarejczyków”

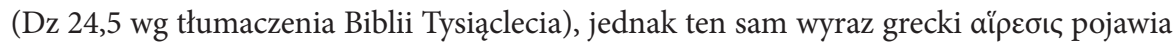
się również wtedy, gdy jest mowa o innych stronnictwach żydowskich, np. Faryzeuszach (Dz 15,5) i Saduceuszach (Dz 15,17).

${ }^{26}$ Szczegółowo postać św. Jakuba i wydarzenia związane z jego śmiercią opisuję w książce M. Rucki, Modlitwa Pańska, s. 159-164.

${ }^{27}$ Czas i okoliczności powstania tego listu nie są pewne, jednak datowanie na rok 62 jest bardzo prawdopodobne. 
przez ofiarę ciała Jezusa Chrystusa raz na zawsze” (Hbr 10,10) oraz „już więcej nie zachodzi potrzeba ofiary za grzechy” $(10,18)$.

Mimo to są podstawy, by uznać, że „sekta nazarejczyków” nadal uważała siebie za pełnoprawnych wyznawców judaizmu, a jej przedstawiciele nadal uczęszczali do Świątyni i do synagog, by się modlić razem z innymi żydami. Świadczy o tym m.in. fakt, że w latach 90. I wieku rabini postanowili wyeliminować ich $\mathrm{z}$ synagogi, wprowadzając do nabożeństwa formułkę „przeciwko zdrajcom” (Berachot 27b). Jak wyjaśnia komentarz do współczesnego modlitewnika żydowskiego ${ }^{28}$, w formułce tej pojawiały się nazwy minim („heretycy”), meszumadim („wychrzty”), malszinim („donosiciele”) oraz nocrim (czyli żydowscy przedstawiciele „sekty nazarejczyków”). Słowa tej formułki były dla wyznawców Jezusa nie do przyjęcia, więc jeśli w czasie nabożeństwa ktoś je pomijał, był wydalany z synagogi jako wychrzta i zdrajca (Berachot 29a). Naturalnie, formułka ta nie dotyczyła chrześcijan pochodzenia pogańskiego, którzy przecież do synagogi nie chodzili.

Ponadto Justyn Męczennik wspomina, że Bar Kochba posunął się jeszcze dalej i kazał torturować Żydów wyznających Jezusa Chrystusa, domagając się, by się Go zaparli i Mu bluźnilii ${ }^{29}$. Pośrednio fakt ten świadczy o tym, że nadal uważał ich za żydów, którzy zbłądzili i odeszli od prawdziwego judaizmu - pragnął ich w ten sposób skłonić do porzucenia wiary, którą uznawał za błąd. Czuł się w obowiązku tak czynić ze względu na wzajemną odpowiedzialność żydów za czystość wiary i za nieszczęścia spadające na cały Izrael z powodu odstępstwa niektórych $\mathrm{z}$ nich ${ }^{30}$. Obcych przecież nie torturowałby i nie zmuszał do przejścia na judaizm. Nie był to jakiś wymysł Bar Kochby, gdyż Dokument Damasceński z I w. przed Chr., uznawany za regułę żydowskiej sekty zamieszkującej okolice Damaszku, przypomina, że „każdy odrzucający wyroki te [...] za bunt ze społeczności winien zostać usunięty” (4Q266 18,5,5-8) $)^{31}$. Według

${ }^{28}$ Sidur Sza'arej, s. XLIV-XLV.

29 1. Apologia, 29.

${ }^{30} \mathrm{O}$ takim podejściu mówi traktat talmudyczny Szewuot 39a, gdzie kwestię wzajemnej odpowiedzialności Żydów wyjaśnia się w nawiązaniu do Kpł 26,37. Całość podsumowuje zdanie: „[Wszyscy] są ukarani, ponieważ mogli zapobiec grzechowi [innych Żydów], ale nie uczynili tego" (Szewuot 39b).

${ }^{31}$ Cyt. za: P. Muchowski, Rękopisy znad Morza Martwego, Kraków 1996, s. 218-219. 
traktatu talmudycznego Sanhedrin 45b bałwochwalstwo jest karane przez ukamienowanie i zawieszenie zwłok bałwochwalcy na palu. Jest to przypadek, w którym nie jest przewidywane przebłaganie ani ofiara za grzech. Rabbi Akiba $^{32}$ natomiast uważał, że bałwochwalstwo kwalifikuje do dwukrotnego „wycięcia” żyda - w tym świecie oraz w przyszłym (Sanhedrin 64b). A przecież oddawanie czci Jezusowi jako Bogu wyglądało w oczach żydów jak bałwochwalstwo.

Należy w tym kontekście odnotować, że przed powstaniem w latach 66-73, kiedy w judaizmie było więcej silnych stronnictw (np. zeloci, esseńczycy, saduceusze $\mathrm{i}$ in.), każde $\mathrm{z}$ nich uznawało wszystkich pozostałych za zdrajców, których należałoby wyeliminować w celu oczyszczenia Izraela ${ }^{33}$. Ten brak jedności i wzajemne zwalczanie się żydów Józef Flawiusz uważał za jedną z przyczyn upadku Jerozolimy ${ }^{34}$. Oczywiście, żydowscy wyznawcy Chrystusa, ubolewając nad losem swojego narodu, byli przekonani, że tragicznych wydarzeń można byłoby uniknąć, gdyby cały Izrael rozpoznał w Jezusie swojego Mesjasza i Syna Bożego.

Euzebiusz z Cezarei potwierdza, że aż do klęski powstania wznieconego przez „fałszywego mesjasza” Bar Kochbę w 135 r. po Chr. wspólnotą wierzących w Jerozolimie kierowali biskupi pochodzenia żydowskiego ${ }^{35}$. Wydaje się zatem zupełnie naturalne, że właśnie w żydowskim Kościele w Jerozolimie, któremu nie był obojętny los kraju i narodu żydowskiego, w latach 70-135 pojawiło się jajko wielkanocne w swoim pierwotnym żałobnym znaczeniu, nawiązującym do zburzenia Jerozolimy. Nic dziwnego nie byłoby również $\mathrm{w}$ tym, gdyby inni biskupi zaakceptowali ten zwyczaj, zwłaszcza że wielu z nich wywodziło się z judaizmu ${ }^{36}$. Przecież nawet dzisiejsi Żydzi Mesjaniczni, wierzący w Jezusa jako żydowskiego

${ }^{32}$ Rabbi Akiba ben Josef był jednym z największych autorytetów rabinicznych II w. po Chr., mimo że popełnił fatalny błąd, uznając Szymona bar Kochbę za Mesjasza. Zginął śmiercią męczeńską w $135 \mathrm{r}$.

${ }_{33}$ Zob. np. M. Rucki, Uczeń Jezusa rozmawia z rabinem, Poznań 2012, s. 46-47.

${ }^{34}$ Wojna żydowska, VIII,1.

${ }^{35}$ Historia Kościelna, IV,6,4.

${ }^{36}$ Przykładowo, Żydem był Klemens Rzymski pełniący obowiązki biskupa Rzymu w latach 91-101, Justus będący biskupem Aleksandrii w latach 118-129, prawdopodobnie również Zachariasz wymieniany w sukcesji apostolskiej Kościoła ormiańskiego w latach 68-72. 
Mesjasza, dokładnie w taki sposób (jako znak żałoby po zburzonej Świątyni jerozolimskiej) rozumieją obecność jajka na stole wielkanocnym ${ }^{37}$. Jednak wierzący z narodów pogańskich widzieli w nim zupełnie inną symbolikę, dzięki której jajko zakorzeniło się w chrześcijańskiej Wielkanocy w postaci pisanek.

\section{JAJKO W TRADYCJI KOŚCIOŁÓW ANTIOCHEŃSKICH}

Gdyby za pomocą kilku słów można było scharakteryzować chrześcijaństwo wschodnie, które narodziło się i rozwijało w klimacie semickim, wystarczyłoby przytoczyć fragment wiersza autorstwa jednego z wybitnych ojców Kościoła, św. Jakuba z Sarug (†521): „Świątynie, gdzie czci się Boga, są teraz wszędzie tam, gdzie znajdują się chrześcijanie"38. Jurysdykcję nad rozległym obszarem chrześcijaństwa wschodniego sprawowała Antiochia, chronologicznie druga po Jerozolimie stolica apostolska. Właśnie w Antiochii uczniowie nazwali siebie chrześcijanami (obyśmy powrócili do tej wspólnej nazwy bez podziału na denominacje) i z niej apostołowie, w tym św. św. Piotr i Paweł, wyruszyli w świat.

Antiochia była wielkim miastem. Już w roku 37 powstała w niej wspólnota Kościoła składająca się z pogan, a nie Żydów ${ }^{39}$. Dzieje Apostolskie $(11,20)$ nazywają ich Grekami, jednak wiadomo, że znaczna liczba mieszkańców Antiochii I wieku wywodziła się z Asyryjczyków. Posługiwali się oni językiem aramejskim, zbliżonym do języka mówionego przez izraelskich i babilońskich Żydów, co w znacznym stopniu znosiło barierę kulturową. Dodatkowo przekaz Ewangelii Asyryjczykom ułatwiało istnienie od czasów wygnania babilońskiego aramejskich tłumaczeń Biblii Hebrajskiej (Targumów) ${ }^{40}$. Obecnie istnieje pięć Kościołów wywodzących

37 Messianic Passover Haggada, Jerusalem 2006, s. 5.

${ }^{38}$ B. Al-Faghali, Jakub As-Surudżi: Kannarat ar-ruh wa kisarat al-bía, Bejrut 1991, s. 182 .

39 Wprawdzie Dzieje Apostolskie wspominają najpierw o nawróceniu dużej liczby Samarytan $(8,14)$, jednak nie był to naród pogański: nie będąc etnicznie Żydami, Samarytanie wyznawali własną formę judaizmu (zob. 2Krl 17,24-28).

40 Zob. np. Encyclopaedia Britannica, http://www.britannica.com/EBchecked/ topic/583515/Targum [dostęp 20.10.2014 r.]. 
się z Antiochii, z których trzy zachowały język liturgiczny aramejski ${ }^{41}$. W Tur Abdinie na terenie dzisiejszej Turcji już w IV wieku działała asyryjska akademia chrześcijańska, dokładnie opisana przez Pigulewską ${ }^{42}$. Założył ją św. Jakub († 338), uczestnik I Soboru Powszechnego, i w niej do roku 363 nauczał słynny św. Efrem. W roku 397 powstał klasztor Mor Gabriel, funkcjonujący do dziśt ${ }^{43}$. W VI stuleciu w Tur Abdinie czynnych było 49 klasztorów asyryjskich ${ }^{44}$, a w VII w. na terenie Mezopotamii działało blisko sto klasztorów ${ }^{45}$.

Asyryjczycy nadal żyją na swojej ojczystej ziemi na pograniczu syryjsko-turecko-irackim, jednak liczba ich drastycznie spadła wskutek masakr w Turcji w okresie I wojny światowej oraz w wyniku uaktywnienia radykalnego islamu w dzisiejszej Syrii i Iraku. Jesteśmy świadkami prawdziwej katastrofy chrześcijaństwa asyryjskiego, które trwało przez dwa tysiące lat i stworzyło cywilizację chrześcijańską na terenie Mezopotamii, Persji oraz Indii.

W kulturze Asyryjczyków na Bliskim Wschodzie jajko jest symbolem świąt wielkanocnych, nawiązującym do zmartwychwstania Chrystusa. Z jajkami są związane rozmaite zwyczaje ludowe i zabawy, które zachowały się również na emigracji. $Z$ badań przeprowadzonych w ostatnich latach XX wieku wśród asyryjskich emigrantów w Szwecji, pochodzących $\mathrm{z}$ różnych krajów ${ }^{46}$, wynika, że wszyscy jednakowo interpretują znaczenie jajek wielkanocnych i z okazji świąt kupują ich więcej niż kiedykolwiek w ciągu całego roku. Średnio na każdą osobę w rodzinie przypada aż 22,3

${ }^{41}$ Są to Kościoły: Syriacki prawosławny (Syriac Orthodox), Syriacki katolicki (Syriac Catholic) i Syriacki Maronicki (Syriac Maronite), natomiast Melkicki grekokatolicki (Melkite Greek Catholic) oraz Antiocheński grecki prawosławny (Antiochian Greek Orthodox) posługują się przeważnie językami greckim i arabskim (za: http:// en.wikipedia.org/wiki/Church_of_Antioch).

${ }^{42}$ N. W. Pigulewska, Kultura syryjska we wczesnym średniowieczu, Warszawa 1988 .

${ }^{43}$ M. Abdalla, Między świętościa a barbarzyństwem. 1600 lat asyryjskiego monasteru $w$ Turcji, „Przegląd Prawosławny” 1998, s. 1, 23-24, 32. Oficjalna strona klasztoru http://www.morgabriel.org/history.html [dostęp 20.10.2014 r.].

${ }^{44}$ H. Anschutz, Die Syrische Christen vom Tur Abdin, Wurzburg 1985, mapy.

45 A. Scher, Tarich Kaldo wa Aszur, Bejrut 1913, t. II, s. 268.

${ }^{46}$ M. Abdalla, Stan i perspektywy kuchni narodowej asyryjskich emigrantów w Szwecji, „Lud” t. LXXXI (1997), s. 173-200. 
jajka, przy czym respondenci zaznaczali, że kupują ich w Szwecji prawie tyle samo, ile kupowali w kraju macierzystym.

Część jajek jest dekorowana symbolami narodowymi lub religijnymi; istnieje również zwyczaj spożywania ich na cmentarzu przy grobach najbliższych w niedzielę następującą po Wielkanocy. Od czasów starożytnych bowiem Kościoły Wschodu widzą w jajku symbol zmartwychwstania - podobnie jak pisklę, które w odpowiednim momencie opuszcza skorupę jajka, tak też Chrystus z własnej woli i bez niczyjej pomocy opuścił grób. Należy ponadto uzmysłowić fakt, że właśnie w jajku jest skupiona siła witalna i że białko jajka uchodzi za wzorcowe, do którego porównuje się białko wszystkich innych środków spożywczych. Czy te wyróżniki zadecydowały o tym, że właśnie jajko, a nie inny pokarm, jest pierwszym poczęstunkiem świątecznym po siedmiu tygodniach ścisłego Wielkiego Postu, podczas którego asyryjscy chrześcijanie eliminują z jadłospisu wszelkie produkty, nawet śladowe składniki, pochodzenia zwierzęcego, w tym oczywiście także jajka? W ich świadomości głęboko tkwi przekonanie, że post jest okresem przygotowawczym do powitania - zarówno w sferze duchowej, jak i fizycznej - każdego ważnego święta kościelnego.

W jednym z wielkanocnych kazań asyryjski ksiądz w berlińskiej parafii wykorzystał grę słów, by wyjaśnić symboliczne znaczenie pisanek. Mianowicie w języku aramejskim, którym do dziś posługują się Asyryjczycy, wyraz „jajko" brzmi dwojako: bi'to albo barto. Ten drugi wyraz może oznaczać również „kobietę”. Ksiądz dopatrzył się w tym aluzji do faktu, że o zmartwychwstaniu Jezusa pierwsze dowiedziały się właśnie kobiety i to one przekazały radosną wieść pozostałym.

Nie ulega wątpliwości, że już w pierwszych wiekach jajko było nieodłącznym elementem świętowania Wielkanocy, a w świadomości pogan wręcz symbolem Kościoła. Dla przykładu, u arabskojęzycznych chrześcijan funkcjonuje wyraz bia oznaczający „kościół”, zapożyczony z języka aramejskiego: bi’to. Nie brak poglądów, że to określenie nawiązuje do kopuły mającej kształt jajka, z daleka widocznej na budynku kościelnym. Ze względu na gorący klimat część kopuły o każdej porze w ciągu dnia, w którym świeci słońce, jest w cieniu, co zapewnia cyrkulację powietrza wewnątrz obiektu.

W jednym ze swoich licznych utworów „O wierze” św. Efrem, najwcześniejszy i zarazem najwybitniejszy poeta wykładający teologię 
wierszem, podkreśla, że moc wzroku luminescencyjnego oka wiary wymaga wzmożonego wzniesienia chwały Stwórcy. W przeciwnym razie wiara pozostaje niczym pisklę niezdolne do rozbicia skorupy jajka, aby z niego się wydostać. Pisze on: „Pisklę, które jeszcze się nie ukształtowało w pełni, w swojej słabości nie jest w stanie rozbijać skorupy, w której tkwi. Tak też wiara zamknięta milczeniem jest słaba. (Boże), który wszystko wypełnia, nadaj jej pełnego kształtu". Podobnie przywołuje przykład młodego ptaka, który dla pełnego rozwoju musi mieć skrzydła: „Ptak kształtuje się trzema etapami; od zarodka do jajka, a od jajka do gniazda, gdzie zaczyna śpiewać. A kiedy jest już rozwinięty, lata na niebie, rozwijając swoje skrzydła niczym znak krzyża" ${ }^{37}$. Świat obrazów, znaków i symboli u św. Efrema jest bardzo bogaty. On widzi je wszędzie: „Chwała Synowi, Panu znaków, który wypełnił wszystkie znaki przez swoje ukrzyżowanie"48.

Warto odnotować, że chociaż w starożytnych opowiadaniach mitologicznych Wschodu jajko występuje jako tajemniczy symbol nowego życia $^{49}$, to jednak prawie nie wspomina się o jajkach np. w pracach Spence'a ${ }^{50}$ czy Hilprechta ${ }^{51}$ poświęconych Asyrii i Babilonii. Pomimo krążących opinii o wpływie kultu bogini Isztar na symbolikę wielkanocną nie ma wyraźnego związku między tym kultem a jajkiem² ${ }^{52}$ Pośrednio może to świadczyć o tym, że uznanie jajka za wielkanocny symbol zmartwychwstałego Chrystusa nie odbyło się automatycznie w celu zachowania wcześniejszych pogańskich zwyczajów, tylko nastąpiło w okresie późniejszym, po zburzeniu Świątyni, kiedy zostało wprowadzone do wieczerzy paschalnej Kościoła.

${ }^{47}$ S. Brock, The luminous eye. The Spiritual World Vision of St. Ephrem, w arabskim tłumaczeniu dokonanym przez o. Josepha Tarzi, Los Angeles 1992, s. 61-62.

48 J.E. Walters (tłumaczenie i wprowadzenie), Ephrem the Syrian's Hymns on the Unleavened Bread, Gorgias Press 2012, s. 25.

49 Zob. np. G. Lerner, The Creation of Patriarchy, New York 1986, s. 149.

${ }^{50}$ L. Spence, Myths and Legends of Babylonia and Assyria, New York 1917.

51 The Excavations in Assyria and Babylonia, H.V. Hilprecht (red.), Philadelphia 1904.

${ }^{52}$ K. D'Costa, Beyond Ishtar: The Tradition of Eggs at Easter, "Anthropology in Practice", March 31, 2013, http://blogs.scientificamerican.com/anthropology-in-practice/ [dostęp 9.11.2014 r.]. 


\section{JAJKO W TRADYCJI EGIPTU}

W życiu narodu, którego historia jest liczona przez wieki, a największa Świątynia trwa nieprzerwanie ponad dwa tysiące lat, pojedyncze lata mogą wydawać się nieznaczące. Jednak dwa wydarzenia w krótkim okresie zmieniły cały bieg życia narodu egipskiego. Chodzi o czas, kiedy Egipt odwiedziła Święta Rodzina ${ }^{53}$, a po kilkudziesięciu latach przybył tu św. Marek Ewangelista, założyciel Kościoła koptyjskiego (egipskiego) i pierwszy patriarcha Aleksandrii ${ }^{54}$.

Tradycja Kościoła koptyjskiego podkreśla, że przed rozpoczęciem posługi ewangelizacyjnej św. Marka w Egipcie co najmniej jedno pokolenie było świadkiem i najprawdopodobniej kilka kolejnych pokoleń słyszało o tej niezwykłej i osobliwej Świętej Rodzinie, która przebywała na ziemi egipskiej. Nowy Testament wspomina też o innych osobach, które udawały się do Egiptu (np. Dz 2,10, Dz 18,24-28), jakby przygotowując grunt do ewangelizacji. Co więcej, tradycja koptyjska mówi o młodzieńcu zwanym Eudaemon (św. Wadamon al-Armanty) ${ }^{55}$, który został pierwszym chrześcijańskim męczennikiem Egiptu, jeszcze przed śmiercią męczeńską św. Marka w 68 r.

Pod koniec I w. przed Chr. mieszkańcy Egiptu byli podzieleni, z grubsza rzecz biorąc, na trzy grupy narodowościowe - Greków, Żydów i Egipcjan; ta ostatnia miała ogromną przewagę liczebną. Każdy z narodów trzymał się swojej religii. Starożytna religia Egipcjan ustąpiła animalizmowi, a duchowe i moralne elementy zanikły lub przekształciły się w niewiarygodne przesądy. Czczenie zwierząt i ptaków było przyczyną zaciętych rywalizacji, które od czasu do czasu prowadziły do wojny między poszczególnymi wyznawcami ${ }^{56}$. Eudaemon usłyszał o Świętej Rodzinie, która przybyła do miasta Al-Aszmunijn (Hermopolis Magna)

53 Mt 2,14-15.

${ }^{54}$ E.L. Butcher, The Story of the Church of Egypt, t. 1, London 1897, List of Patriarchs of the Church of Egypt, s. XIII.

${ }^{55}$ W koptyjskim Synaksarionie jest wspominany 18. dnia miesiąca Mesore. Zob. np. Synaxarium, [w:] St. Mina Coptic Orthodox, <http://www.saintminas.com/index. php/2013-05-30-02-12-56/synaxarium?task=the_days\&sm=0-2\&c=\&iday=30\&imonth= 6\&iyear $=2014 \& \mathrm{dbl}=\mathrm{en} \& \mathrm{rdr}=\mathrm{misra} /$ day18.php $>$ [dostęp 10.11.2014 r.].

${ }_{56}$ Zob. E.L. Butcher, dz. cyt., s. 2-4. 
w Górnym Egipcie, i zapragnął spotkać dzieciątko „przypominające syna królów" ${ }^{7}$. Mały Jezus pobłogosławił młodzieńca i powiedział mu, że jego domem na wieki będzie kościół. Po powrocie do domu Eudaemon został zamordowany przez pogan, jak tylko zaczął mówić ludziom o Jezusie i jego matce, Maryi Pannie. Kiedy chrześcijaństwo zostało zaakceptowane na terenie Egiptu, w miejscu, gdzie stał dom św. Wadamona al-Armantiego, wzniesiono kościół pw. Nieśmiertelnego. Kościół ten istnieje po dziś dzień w mieście Armant (Hermonthis) w Górnym Egipcie ${ }^{58}$.

Święty Marek natomiast przybył do Egiptu w 45 roku po Chr. ${ }^{59} \mathrm{Kie}-$ dy szedł ulicami Aleksandrii, pasek na jego sandałach rozdarł się i apostoł zwrócił się o pomoc do szewca o imieniu Annianus. Podczas gdy szewc pracował, szydło przebiło mu rękę; podniósł ją w górę, wykrzykując po grecku: „Eis Theos” ('jeden Bóg’). Św. Marek spytał „czy znasz Boga?”. Annianus odpowiedział: „Słyszałem o Nim, ale nie znam Go” ${ }^{60}$. Apostoł uznał wtedy, że może rozpocząć rozmowę o Jedynym Bogu. Wziął trochę gliny, splunął na nią i przyłożył do rany szewca, uzdrawiając jego rękę. Zaczął mówić mu o Bogu Ojcu i Jego Synu, Jezusie Chrystusie, i Annianus wraz z całą rodziną przyjął chrzest. Tak rozpoczęły się dzieje Kościoła założonego przez św. Marka w Egipcie. Wkrótce św. Marek wyświęcił Annianusa na biskupa Aleksandrii, a z nim trzech kapłanów i siedmiu diakonów ${ }^{61}$. Tak więc Egipt - niegdyś wielkie państwo pogan - już od czasów Jezusa Chrystusa przekształcił się w chrześcijańską potęgę i żyzną glebę dla świętych oraz męczenników.

Kościół egipski zaakceptował wiele ze zwyczajów starożytnych Egipcjan. Połączono je z religią, lecz nie wtopiono w system ideologiczny, co nadawało im nowe znaczenie symboliczne. Na przykład używanie komży - białej lnianej szaty kapłanów Izydy; praktykowanie tonsury, która wyróżniała egipskich kapłanów; czy pierścień noszony na znak zawartego małżeństwa. Zwyczaje te były nadal praktykowane wśród Egipcjan po ich konwersji na chrześcijaństwo, obchodzono również uroczystość powitania

57 Synaksarion, Mesore 18.

58 Tamże.

59 E.L. Butcher, dz. cyt., s. 21.

${ }^{60}$ I.H. El-Misri, The Story of the Copts: The True Story of Christianity in Egypt, Newberry Springs-Calif. 1982, s. 16.

${ }^{61}$ Synaksarion, Parmoude 30. 
wiosny w dniu równonocy wiosennej, w którym świat został stworzony (według starożytnych przekonań). Święto to nosiło nazwę szom ennisim (w zarabizowanej formie nazywa się Szam an-Nasim). Tradycyjne potrawy spożywane w tym dniu składały się głównie z solonej ryby (szary mullet), sałaty, dymki, zielonej ciecierzycy i kolorowanych jajek ugotowanych na twardo.

Wraz z rozprzestrzenieniem się chrześcijaństwa w Egipcie obchodzenie święta powitania wiosny stało się niemożliwe. Szom ennisim przypadało bowiem na okres Wielkiego Postu poprzedzającego święta wielkanocne, a w czasie Postu Koptowie powstrzymywali się od jedzenia ryb i mięsa wszelkiego rodzaju oraz innych produktów pochodzenia zwierzęcego: mleka, jajek czy masła. Unikali zabaw i organizowania wesel. Spożywali tylko owoce i warzywa, zarówno surowe, jak i gotowane na wodzie lub w oleju roślinnym, ryż, rośliny strączkowe, szczególnie bób, a czasami jedli sam tylko chleb. Stąd Koptowie zdecydowali o przeniesieniu święta szom ennisim na dzień następujący po świętach wielkanocnych. Powiązanie powitania wiosny ze zmartwychwstaniem Jezusa Chrystusa uznawali za słuszne ze względu na głębokie duchowe znaczenie: zmartwychwstanie Chrystusa otworzyło ponownie bramy raju, które zostały zamknięte z powodu grzechu Adama i Ewy $(\operatorname{Rdz} 3,3)^{62}$.

Jaja na stole powitania wiosny były jednym ze świętych obrzędów. Dla starożytnych Egipcjan symbolizowały one stworzenie życia z nieożywionych przedmiotów i były znakiem nadziei powrotu do życia po śmierci. W starożytnej mitologii egipskiej Ptah, bóg bogów, który stanowił jedną z wielkich sił stwórczych, stworzył kosmiczne jajo, z którego „wykluł się" świat ${ }^{63}$. Kościół koptyjski zaakceptował ten mit, traktując go jako zapowiedź prawdy o zmartwychwstaniu oraz transformacji człowieka. Dla Kościoła jajo stało się symbolem grobu Chrystusa i Jego zmartwychwstania - z zewnątrz wygląda na nieożywione, jednak w środku jest żywe.

${ }^{62}$ Karas al-Muharraki [mnich], Adat szabijja [Ludowe zwyczaje], Al-Kahira b.r.w., s. 10-11.

${ }^{63}$ E.A. Wallis Budge, A Guide to the Third and Fourth Egyptian Rooms, London 1904, s. 191. 
Wprawdzie tradycja zdobienia jaj na święta i dla zabawy była znana od czasów starożytnych ${ }^{64}$, ale jajka wielkanocne były malowane na jednolity czerwony kolor symbolizujący przelanie krwi Chrystusa na krzyżu, Nowe Przymierze zawarte między Bogiem i ludźmi. Zwyczaj ten najprawdopodobniej przeszedł z Ziemi Świętej i miał na celu odróżnienie jaj wielkanocnych od jaj paschalnych ${ }^{65}$, które oznaczały żałobę w tradycji żydowskiej ${ }^{66}$. Jeśli chodzi o barwienie jaj na różne kolory, to mogło się ono pojawić w XIII wieku w związku z różnymi wpływami kulturowymi ${ }^{67}$. $\mathrm{Z}$ powodu gromadzenia $\mathrm{w}$ okresie postu jajek $\mathrm{w}$ dużych ilościach niegdyś koptyjscy kapłani zbierali te nadwyżki do podziału wśród wiernych po mszy świętej rezurekcyjnej ${ }^{68}$. Pomimo chrześcijańskiego charakteru święta jest ono nadal obchodzone w pierwotnym kształcie przez wszystkich Egipcjan, niezależnie od religii, jako święto narodowe, z pominięciem przesłania religijnego.

Starożytna symbolika związana z jajkami nie kolidowała z myślą i obrzędowością chrześcijańską. Wydmuszki strusich jaj, które były materiałem dekoracyjnym docenianym już przez starożytnych Egipcjan ${ }^{69}$, wieszano w niektórych kościołach przed ikonostasem. Nawet wśród samych Koptów nie ma jednolitego wytłumaczenia znaczenia tego symbolu. Niektórzy dopatrują się symboliki zmartwychwstania w wykluwaniu się piskląt strusia ze skorupki i troskliwej opiece strusia nad swoimi jajami $\mathrm{w}$ okresie inkubacji ${ }^{70}$. Struś bowiem nieustannie wpatruje się $\mathrm{w}$ jaja w gnieździe, aby nie uległy zepsuciu, więc tak samo wierni powinni być czujni, a ich myśli skierowane na sprawy duchowe, a podczas mszy świętej powinni zachowywać postawę $\mathrm{czci}^{71}$. Inne wyjaśnienie wskazuje na przesłanie zapisane w Księdze Hioba: „Żwawe są skrzydła strusia, czy tak jak pióra bociana? Jaja swe rzuca na ziemię, ogrzewa je w piasku,

${ }^{64}$ Por. Mostafa Elshamy, Ancient Egypt the Primal Age of Divine Revelation, t. 1, Cairo 2014, s. 63 i n.

65 E. Satati, Szam an-Nasim, Al-Kahira 2006, s. 46.

${ }^{66}$ Por. wyżej, 1. Jajko w judaizmie.

${ }^{67}$ E. Satati, dz. cyt.

${ }^{68}$ Karas al-Muharraki, dz. cyt., s. 34.

69 Por. Mostafa Elshamy, dz. cyt.

70 T.Y. Malaty [ks.], Dictionary of Church Terms, Alexandria 1992, s. 81.

${ }^{71}$ A. Butler, Ancient Coptic churches of Egypt, Oxford 1884, s. 79. 
zapomina, że można je zdeptać lub że zniszczą je dzikie zwierzęta. Swe dzieci traktuje jak obce, że trud jego próżny, o to się nie boi. Mądrości Bóg go pozbawił, rozsądku mu nie udzielił. Gdy się podniesie i cwałuje, śmieje się z konia i jeźdźca” (39,13-18). Przetrwanie strusia jako gatunku pomimo niedbałego stosunku do złożonych jaj świadczy o tym, że oko Boga, które spoczywa przede wszystkim na człowieku, opiekuje się nim i chroni go. O tym przypominają wiernym strusie jaja zawieszane $\mathrm{w}$ kościołach. Wszakże gdy matka zapomni o swym niemowlęciu, Bóg o nim nie zapomni (por. Iz 49,15) ${ }^{72}$.

Na przykładzie Kościoła koptyjskiego można się przekonać, że nie nastąpiło automatyczne zaadaptowanie pogańskich zwyczajów na potrzeby chrześcijaństwa.

\section{PODSUMOWANIE}

Obserwując znaczące różnice w mitologiach i zwyczajach związanych z jajkami w różnych regionach starożytnego świata, można zauważyć pewne cechy wspólne dla rozumienia tej symboliki przez chrześcijan. Na tej podstawie można przypuszczać, że powiązanie świętowania Wielkanocy z symboliką jajek nastąpiło w Kościele w czasach apostolskich, kiedy związki między Kościołami lokalnymi były bardzo silne, a apostołowie i ich następcy mogli spotykać się w Jerozolimie i osobiście odwiedzali wspólnoty znajdujące się w różnych krajach. Po zmartwychwstaniu Jezusa i zstąpieniu Ducha Świętego w Jerozolimie chrześcijaństwo szybko rozprzestrzeniło się w całej Judei i pobliskiej Samarii, po czym w ciągu kilkudziesięciu lat mocno zakorzeniło się wśród Żydów oraz narodów pogańskich - wychodząc z Judei i Galilei, przyjmowane było i na północnym zachodzie (Azja Mniejsza i Europa), i na południowym zachodzie (Afryka Północna), i na wschodzie (Mezopotamia).

Nie ulega wątpliwości, że jajko było traktowane symbolicznie i nawet magicznie już w świecie pogańskim. Nie musi to jednak oznaczać,

${ }^{72}$ I.A. Farag [ks.], Mukadima fi ilm al-lahut at-taksi [Wprowadzenie do teologii liturgicznej], [online], [w:] Saint Takla Church Official Website, http://st-takla.org/CopticFaith-Creed-Dogma/Coptic-Rite-n-Ritual-Taks-Al-Kanisa/02-Coptic-Rituals-Theology_Fr-Asheia/Orthodox-Church-Rite_020-Beid-El-Na3am.html [dostęp 23.10.2014 r.]. 
jakoby Kościół po prostu zaakceptował pogańską symbolikę i wierzenia, nadając im „chrześcijański” sens. Mimo że w dokumentach starożytnego Kościoła nie zachowały się zapisy wyjaśniające, skąd się wzięło jajko w obchodach Wielkanocy, fakty historyczne i zachowane tradycje zdają się wskazywać na coś więcej. Jest całkiem prawdopodobne, że początkowo w Kościele jajko mogło symbolizować smutek z powodu zburzenia Jerozolimy i Świątyni, jednak zawarty w tym symbolu żydowskim element nadziei pozwolił traktować jajko również jako symbol nowego życia i zmartwychwstania. Liczne mity i zwyczaje, związane z jajkiem w różnych krajach, zostały zaakceptowane przez Kościół jako „zapowiedź rzeczy przyszłych” znajdujących spełnienie w zmartwychwstaniu Jezusa. Dlatego jajko wielkanocne jest czymś o wiele więcej niż tylko „schrystianizowanym" pogańskim symbolem.

Streszczenie. Jajka wielkanocne są obecne tradycjach chrześcijańskiego Wschodu i Zachodu, a także w judaizmie. Mimo że symbolika żydowska (pokarm żałoby), pogańska (kult płodności) i chrześcijańska (zmartwychwstanie) pozornie niewiele mają wspólnego, jednak wydaje się możliwe połączenie tych symboli we wczesnym okresie chrześcijaństwa. W czasie bowiem, kiedy jajko zostało włączone przez Żydów do liturgii paschalnej, Kościół zdobywał nowych wiernych w Europie, Mezopotamii i Afryce Północnej, gdzie często biskupami zostawali wyznawcy Chrystusa pochodzenia żydowskiego. Artykuł omawia warunki historyczno-kulturowe, w jakich jajko zostało włączone do chrześcijańskiego świętowania Wielkanocy w Kościele jerozolimskim, koptyjskim oraz antiocheńskim.

Słowa kluczowe: jajko; Wielkanoc; Koptowie; Asyryjczycy; judeochrześcijaństwo.

Summary. Easter eggs in the early Church. Easter eggs are present in the tradition of the Eastern and Western Church, and in Judaism as well. Despite the seemingly contradiction in the symbolic meaning of the eggs in Judaism (mourning meal), heathen religions (fertility cult) and Christianity (fact of the resurrection), it looks possible to find the common ground for the egg symbol in the early Church. In the period when the egg was added to the Jewish celebration of the Easter (Pesach), mass conversions to Christianity took place in Europe, Mesopotamia and North Africa, where often Jewish believers in Christ became the bishops. The article describes the historical and cultural context of the introduction of the eggs to the Easter celebration in the Coptic, Antiochian and Jerusalem Churches.

Keywords: egg; Easter; Copts; Assyrians; Jewish Christians. 